Article

\title{
Molybdenum Dopped Copper Ferrites as Active Catalysts for Alcohols Oxidative Coupling
}

\author{
Gheorghiţa Mitran ${ }^{1, *}$, Shaojiang Chen ${ }^{2}$ and Dong-Kyun Seo ${ }^{2, *} \mathbb{C}$ \\ 1 Laboratory of Chemical Technology and Catalysis, Department of Organic Chemistry, Biochemistry \& \\ Catalysis, Faculty of Chemistry, University of Bucharest, 4-12, Blv. Regina Elisabeta, 030018 Bucharest, \\ Romania \\ 2 School of Molecular Sciences, Arizona State University, Tempe, AZ 85287-1604, USA; schen178@asu.edu \\ * Correspondence: geta_mitran@yahoo.com (G.M.); DSeo@asu.edu (D.-K.S.); Tel.: +40-021-315-9249 (G.M.)
}

Received: 23 May 2019; Accepted: 5 June 2019; Published: 10 June 2019

Abstract: Copper ferrites dopped with molybdenum were studied in an oxidative coupling reaction between methanol and ethanol in the gas phase. The catalysts have been characterized by X-ray diffraction, where the presence of ferrite, magnetite, and tenorite phases was observed; scanning electron microscopy; UV-Vis spectroscopy; and Fourier-transform infrared spectroscopy, which highlighted the presence of octahedral coordination of isolated molybdena species. The catalyst with the highest activity in this reaction and with the highest selectivity to hydroxyacetone is the one that presents Lewis sites with weak acidity. The methyl and ethyl acetate selectivities are directly proportional to the $\mathrm{Cu} / \mathrm{Fe}$ ratio. It has been observed that the presence of reduced copper sites is responsible for the selectivity in esters, while the presence of reduced iron and molybdenum sites is responsible for the acetol production.

Keywords: oxidative coupling; hydroxyacetone; molybdenum-copper ferrites; methyl acetate; ethyl acetate

\section{Introduction}

Catalytic transformation of methanol and ethanol in products with higher added value has become more and more interesting due to their renewable characteristics. The condensation in the gas phase is a complex process which involves alcohol dehydrogenation (or oxidation) to aldehyde, aldol condensation, coupling reactions [1]. The products from methanol and ethanol reactions can be classified into non-coupling products (do not form $\mathrm{C}-\mathrm{C}$ bonds) such as formaldehyde, acetaldehyde, ethers, methyl, and ethyl acetate and coupling products $\left(\mathrm{C}-\mathrm{C}\right.$ bonds are formed), e.g., $\mathrm{C}_{3}, \mathrm{C}_{4}$ alcohols. A mixture of methanol and ethanol was used in the "Guebert" reaction in order to obtain superior alcohols (1-propanol, 1-butanol) [2].

The acyloin condensation is an interesting method which involves $C-C$ bond formation and consists of an intermolecular condensation of two molecules of aldehydes; the main product of this reaction is a $\alpha$-hydroxy ketone [3]. The reaction takes place in the presence of basic catalysts.

Acetol (hydroxyacetone) plays an important role as an intermediary in organic synthesis due to its ability to convert to a variety of products by dehydration, hydrogenation, oxidation, and polymerization [4]. Acrolein could be produced by its dehydration, while by its hydrogenation propylene glycol has been obtained. Among other compounds that can be obtained from its reactions are acetone, propionaldehyde, and furan derivates. High reactivity makes it valuable as an intermediary for esters, dioxane, $\alpha$-amino ketones and $\alpha$-amino alcohols. Furthermore, it is used in the food industry to give bread flavor and to induce flavor in milk compounds. In the cosmetic industry, it is used as a constituent of skin tanning agents. 
Glycerol is one of the raw materials used to obtain the acetol in the presence of supported metals. Copper supported on acidic oxides such as $\mathrm{Al}_{2} \mathrm{O}_{3}, \mathrm{ZrO}_{2}, \mathrm{Fe}_{2} \mathrm{O}_{3}$, and $\mathrm{SiO}_{2}$ [5] is very selective towards acetol, while the strong acidic supports such as Keggin-type heteropoly acids and niobium oxides are more selective towards acrolein. The catalysts with high basicity are selective to allyl alcohol, as has been noticed by Kinage [6].

Spinel-type copper ferrites are an attractive class of materials, which are characterized by thermal stability, both redox and acid-base characteristics, and good catalytic properties for many reactions such as alcohol decomposition [7,8], selective oxidation [9-11], methanol steam reforming [12], water gas shift reaction [13], and ethanol oxidation [14]. Iron molybdates have been used as catalysts in photodegradation reactions [15].

The catalytic properties of these materials depend on cations distribution in the octahedral (Oh) and in the tetrahedral (Td) sites of the spinel lattice, respectively, on the presence of weak basic sites, and on a good dispersion of copper.

The purpose of this paper is to investigate the effects of molybdenum loading and of $\mathrm{Fe} / \mathrm{Cu}$ ratio modification on the structural properties of copper ferrites and on the catalytic activity in the oxidative coupling of methanol with ethanol.

\section{Results and Discussion}

\subsection{Catalysts Characterization}

The PXRD (powder X-ray diffraction) (PANalytical, Almelo, The Netherlands) patterns of $\mathrm{CuFe}_{2-2 x} \mathrm{Mo}_{x} \mathrm{O}_{4}$ samples are illustrated in Figure 1. From the diffraction patterns, lines corresponding to copper ferrite with spinel structure $\mathrm{CuO}$ (tenorite, PDF 00-041-0254) with a higher crystallinity $\mathrm{F}_{3} \mathrm{O}_{4}$ phase (magnetite, $\mathrm{PDF}$ 01-071-6336) superimposed with those corresponding to $\mathrm{CuFe}_{2} \mathrm{O}_{4}$ (PDF 00-034-0425) have been observed. The presence of diffraction lines corresponding to crystalline $\mathrm{CuO}$ and to small impurities of reduced $\mathrm{Cu}_{2} \mathrm{O}\left(2 \theta=29,34,41,62,73^{\circ}\right.$, JCPDS 05-0667) phase evidenced that not all $\mathrm{Cu}$ species are incorporated into the $\mathrm{CuFe}_{2} \mathrm{O}_{4}$ spinel. No lines corresponding to molybdenum have been highlighted, probably due to incorporation of Mo ions into the magnetite lattice. The peak positions are shifted to lower $2 \theta$ in the presence of molybdenum, which reveals the presence of microstrains in the structure such as lattice dislocation or oxygen vacancies [16].

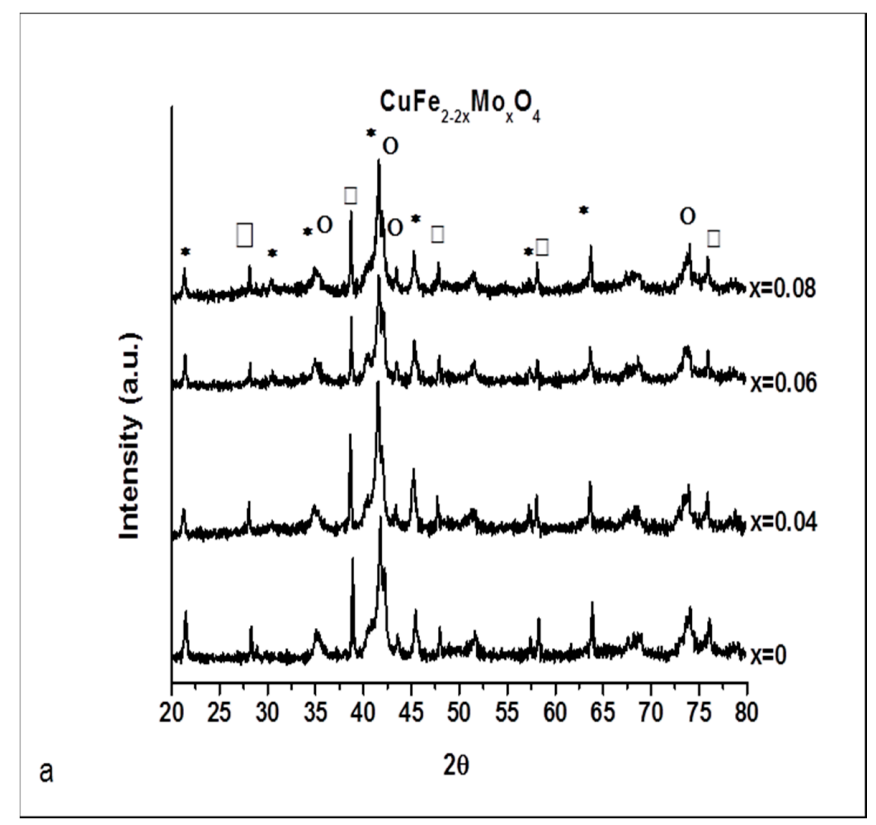

Figure 1. Patterns of the molybdenum doped copper ferrites: ${ }^{*}-\mathrm{CuFe}_{2} \mathrm{O}_{4}, \bigcirc-\mathrm{Fe}_{3} \mathrm{O}_{4}$ (magnetite), $\square-\mathrm{CuO}$ (tenorite). 
The Brunauer-Emmett-Teller BET surface area for all samples evidenced that mixed oxides display smaller specific surface area, in the range $2.8-5.9 \mathrm{~m}^{2} / \mathrm{g}$, that could be attributed to the presence of larger particles as well as to the existence of crystalline phases.

FT-IR spectra (PerkinElmer, Fitchburg, USA) of samples are shown in Figure 2. The bands situated in the range $400-600 \mathrm{~cm}^{-1}$ are characteristic for $\mathrm{Fe}_{3} \mathrm{O}_{4}, \mathrm{CuFe}_{2} \mathrm{O}_{4}$, and $\mathrm{CuO}$ absorption. The band situated at $420 \mathrm{~cm}^{-1}$ corresponds to octahedral metal stretching of $\mathrm{Cu}^{2+}-\mathrm{O}^{2-}$, while $\mathrm{Fe}_{2} \mathrm{O}_{3}$ presents a vibration band at $480 \mathrm{~cm}^{-1}$ [17] and its presence is not observed on the sample with 0.08Mo. The strong absorption bands located at 525-540 $\mathrm{cm}^{-1}$ and those situated in the region $435-445 \mathrm{~cm}^{-1} \mathrm{are}^{-}$ correlated with the presence of Fe-O bending vibration to magnetite and spinel copper ferrites [18] and are attributed to the tetrahedral and octahedral vibration of $\mathrm{M}^{2+} / \mathrm{M}^{3+}$ cations, respectively. The position of these bands is shifted to the higher wavenumber and their intensity decreases in the presence of molybdenum, probably due to the changes induced by the lattice modifications or by the defects in crystal like emergence of unsaturated sites on the surface. The molybdenum characteristic bands appear in the range $800-990 \mathrm{~cm}^{-1}$. The isolated tetrahedral molybdenum species $\mathrm{MoO}_{4}{ }^{2-}$ and two-dimensional polymeric forms to distorted octahedral molybdenum species have characteristic bands at 975 and $950 \mathrm{~cm}^{-1}$ [19]. The band located at $830 \mathrm{~cm}^{-1}$ is assigned to the antisymmetric mode of Mo-O-Mo in $\mathrm{MoO}_{4}{ }^{2-}$ (more pronounced for the sample with $0.06 \mathrm{Mo}$ ).

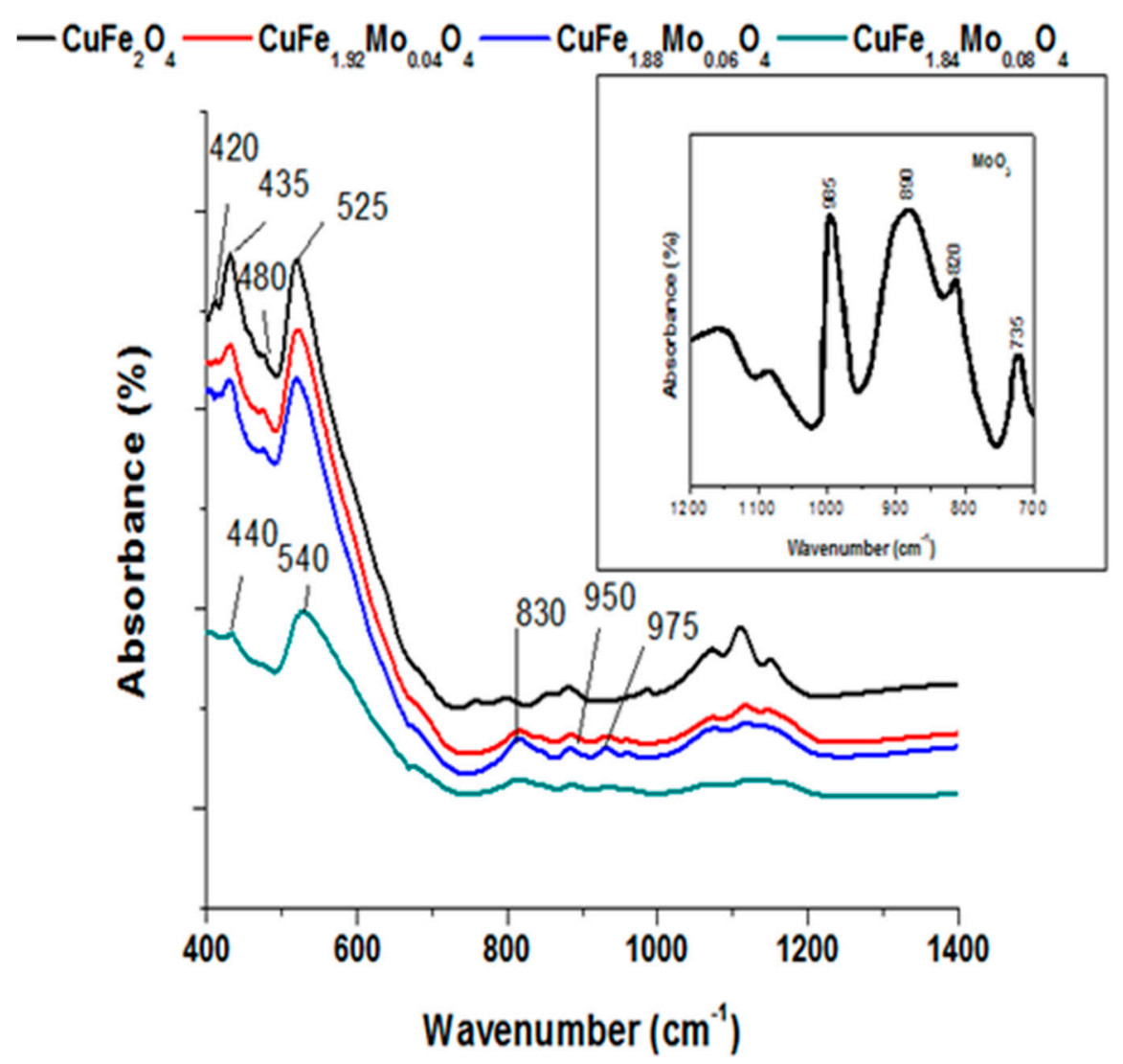

Figure 2. FT-IR spectra of the copper ferrites dopped with molybdenum.

Figure 3 shows the UV-Vis absorption spectra (Shimadzu, Osaka, Japan) of copper-molybdenum ferrites. From the spectra, it was observed that the main absorption band of the samples appears in the wavelength region at 200-250 nm and corresponds to the small crystal size of the particles [20]. Absorption bands located at 300-360 nm have been assigned to an octahedral coordination of isolated molybdenum species [21]. The intensity of absorption band at $355 \mathrm{~nm}$ has been correlated with molybdenum loading on the surface. The band situated at $660 \mathrm{~nm}$ corresponds to d-d transition of 
$\mathrm{Cu}^{2+}$ ions in a distorted octahedral environment [22], but it could also be attributed to the interaction between the two metal, Fe- $\mathrm{Cu}$. Iron oxides corresponding bands are located at 465 and $565 \mathrm{~cm}^{-1}$.

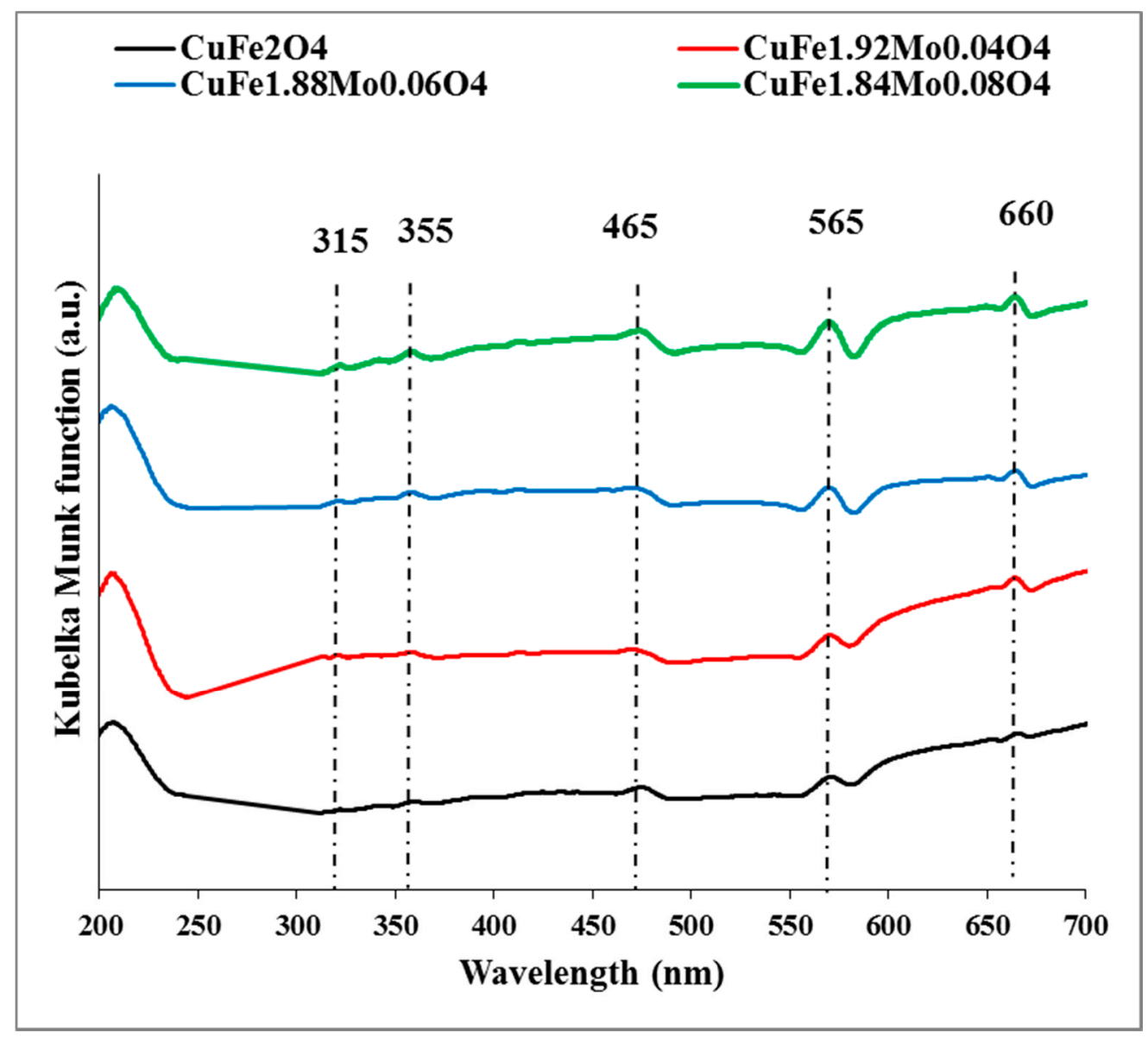

Figure 3. UV-Vis absorption spectra of the copper-molybdenum ferrites.

Scanning electron microscopy (SEM), (FEI Company, Hillsboro, OR, USA) images (Figure 4) highlight the presence of both disordered mesopores and macropores, remarking at the same time heterogeneous nucleation of particles with the appearance of spherical shape crystals. The sample without molybdenum shows the more uniform surface topography whereas in the presence of molybdenum grain agglomeration with an increase in the average particle size has been observed. The images were analyzed by Image J software in order to quantify the particle morphology and the average particle size was $41.3 \mathrm{~nm}\left(\mathrm{CuFe}_{2} \mathrm{O}_{4}\right), 60.9 \mathrm{~nm}\left(\mathrm{CuFe}{ }_{1.92} \mathrm{Mo}_{0.04} \mathrm{O}_{4}\right), 73.1 \mathrm{~nm}\left(\mathrm{CuFe}_{1.88} \mathrm{Mo}_{0.06} \mathrm{O}_{4}\right)$, and $58.3 \mathrm{~nm}\left(\mathrm{CuFe}_{1.84} \mathrm{Mo}_{0.08} \mathrm{O}_{4}\right)$, respectively. 


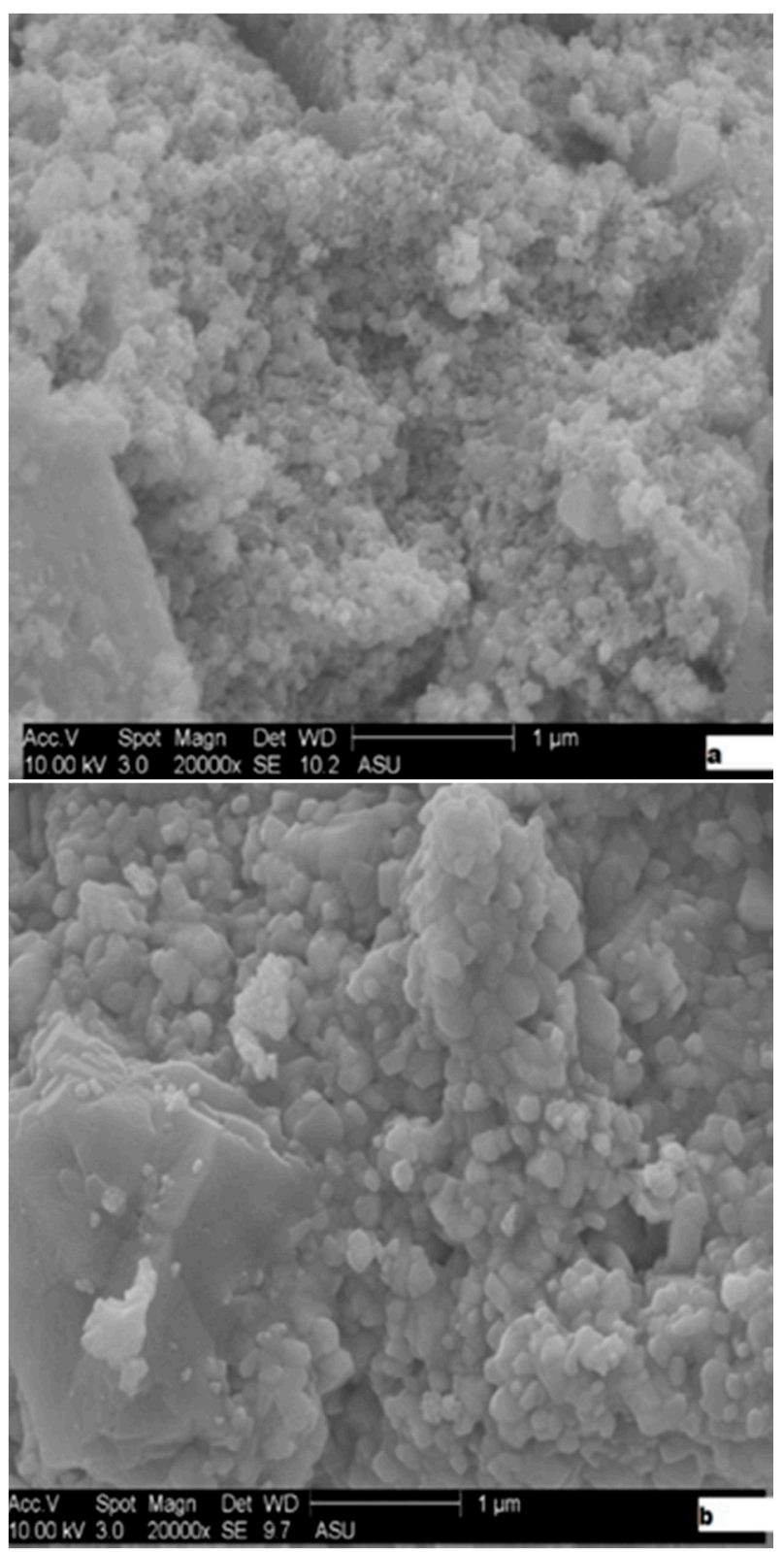

Figure 4. Cont. 

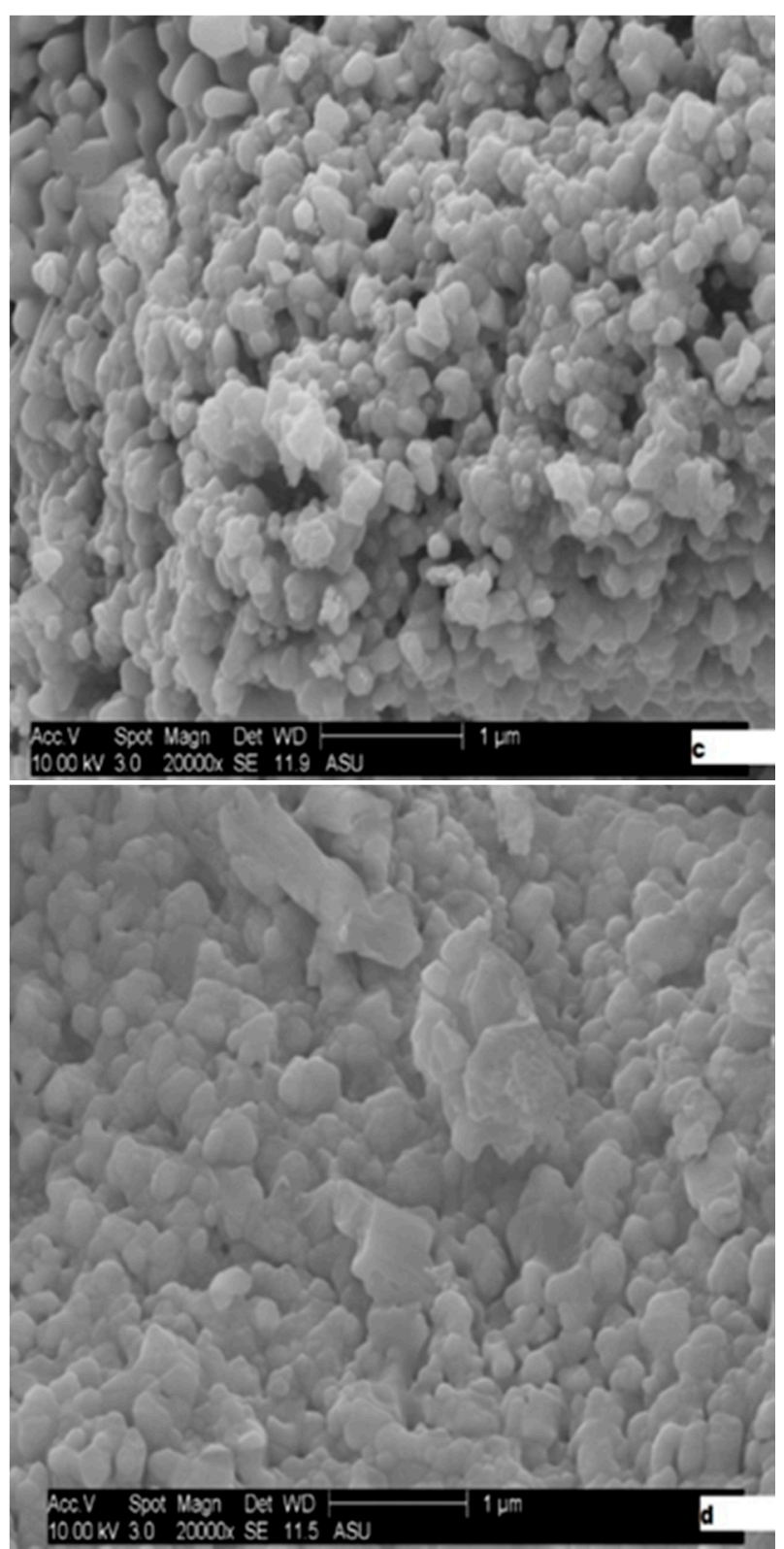

Figure 4. Cont. 

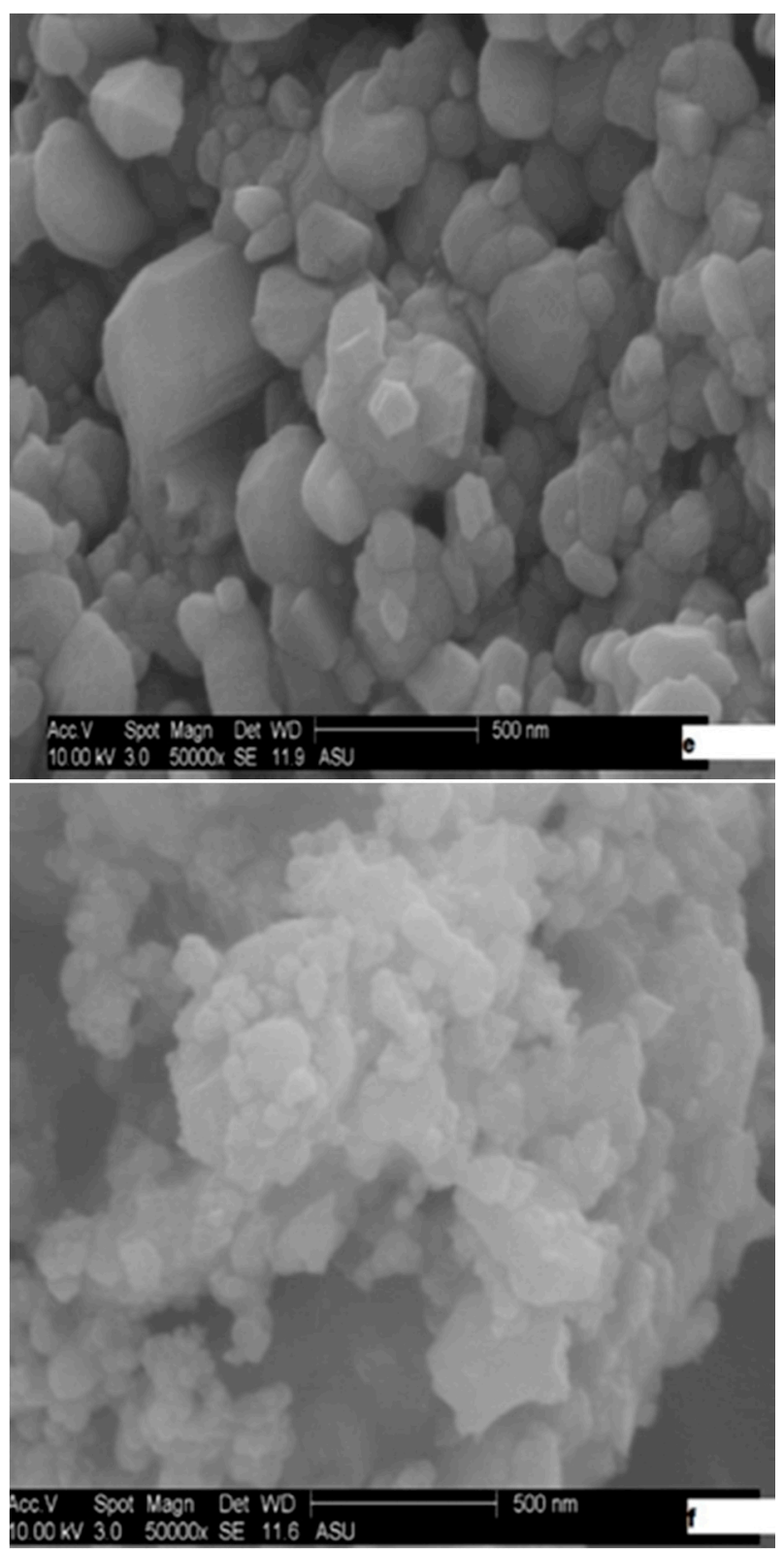

Figure 4. SEM images of the surface morphology of copper ferrites dopped with molybdenum (a) $\mathrm{CuFe}_{2} \mathrm{O}_{4} ;$ (b) $\mathrm{CuFe}_{1.92} \mathrm{Moo}_{0.04} \mathrm{O}_{4} ;$ (c) $\mathrm{CuFe}_{1.88} \mathrm{Mo}_{0.06} \mathrm{O}_{4} ;$ (d) $\mathrm{CuFe}_{1.84} \mathrm{Mo}_{0.08} \mathrm{O}_{4} 1 \mu \mathrm{m}$; (e) $\mathrm{CuFe}_{1.88} \mathrm{Mo}_{0.06} \mathrm{O}_{4} ;$ (f) $\mathrm{CuFe}_{1.84} \mathrm{Mo}_{0.08} \mathrm{O}_{4}, 500 \mathrm{~nm}$.

Chemical composition of samples has been studied through Energy Dispersive Analysis spectrum (EDX) (FEI Company, Hillsboro, OR, USA) and the results are presented in Table 1. From these results the formulas for prepared samples are $\mathrm{CuFe}_{1.93} \mathrm{O}_{4}, \mathrm{CuFe}_{1.2} \mathrm{Mo}_{0.03} \mathrm{O}_{1.98}, \mathrm{CuFe}_{1.35} \mathrm{Mo}_{0.06} \mathrm{O}_{1.66}$, and $\mathrm{CuFe}_{2.14} \mathrm{Mo}_{0.14} \mathrm{O}_{4.31}$. The first sample has a formula very closed to the calculated one; the second and the third samples have values for Mo very close to the calculated ones and $\mathrm{Fe}$ and $\mathrm{O}$ values lower than those calculated; and the fourth sample has higher values than those calculated for Fe, Mo, and $\mathrm{O}$. 
Table 1. Chemical composition of copper ferrites substituted with molybdenum.

\begin{tabular}{lllllllll}
\hline \multirow{2}{*}{ Catalyst } & \multicolumn{4}{c}{ Wt (\%) } & \multicolumn{5}{c}{ At (\%) } \\
\cline { 2 - 9 } & $\mathbf{C u}$ & Fe & Mo & O & Cu & Fe & Mo & O \\
\hline $\mathrm{CuFe}_{2} \mathrm{O}_{4}$ & 27.1 & 45.3 & - & 26.9 & 14.6 & 27.7 & - & 57.6 \\
$\mathrm{CuFe}_{1.92} \mathrm{Mo}_{0.04} \mathrm{O}_{4}$ & 38.7 & 40.5 & 1.7 & 19.1 & 24.0 & 28.5 & 0.7 & 46.8 \\
$\mathrm{CuFe}_{1.88} \mathrm{Mo}_{0.06} \mathrm{O}_{4}$ & 37.2 & 43.7 & 3.6 & 15.4 & 24.7 & 33.0 & 1.6 & 40.7 \\
$\mathrm{CuFe}_{1.84} \mathrm{Mo}_{0.08} \mathrm{O}_{4}$ & 24.0 & 45.0 & 5.2 & 25.9 & 13.3 & 28.2 & 1.9 & 56.7 \\
\hline
\end{tabular}

X-ray photoelectron spectroscopy (Kratos, Manchester, UK) results and surface composition estimated from XPS are shown in Figure 5 and Table 2. In order to calibrate the obtained spectra, the binding energies were corrected relative to the carbon $1 \mathrm{~s}$ signal at $284.8 \mathrm{eV}$. It could be observed that the binding energy positions of $\mathrm{Cu} 2 \mathrm{p}$ are located at $930.9 \mathrm{eV}(\mathrm{Cu} 2 \mathrm{p} 3 / 2)$ and $951.6 \mathrm{eV}(\mathrm{Cu} 2 \mathrm{p} 1 / 2)$ corresponding to $\mathrm{Cu}^{+}$, the peaks at $933.5 \mathrm{eV}(\mathrm{Cu} 2 \mathrm{p} 3 / 2)$ and $954.2 \mathrm{eV}(\mathrm{Cu} 2 \mathrm{p} 1 / 2)$ are related to $\mathrm{Cu}^{2+}$ [23] and four satellites at 936, 941.9, 960.1, and $963.2 \mathrm{eV}$. The binding energies of $\mathrm{Cu}$ species indicate that in all samples both $\mathrm{Cu}^{+}$and $\mathrm{Cu}^{2+}$ are present on the surface (except for the sample with $0.06 \mathrm{Mo}$ where only $\mathrm{Cu}^{2+}$ was present). The Fe $2 p$ peaks are split into two components: $\mathrm{Fe} 2 \mathrm{p} 3 / 2$ and Fe 2p1/2. The peak assigned to metallic iron $\left(\mathrm{Fe}^{0}\right)$ located at $707.3 \mathrm{eV}$ and $722.2 \mathrm{eV}$ is present on the sample with $0.06 \mathrm{Mo}$ (that contains $\mathrm{Fe}^{0}$ and $\mathrm{Fe}^{3+}$ ), while the other samples present peak at $709.8(0.5) \mathrm{eV}$ and 723.5 $( \pm 0.7 \mathrm{eV})$ with two satellites corresponding to $\mathrm{Fe}^{2+}$ and the peaks associated to $\mathrm{Fe}^{3+}$ with a maximum at $710.5( \pm 0.8) \mathrm{eV}$ and $724.5 \mathrm{eV}$ [24]. The Mo 3d spectrum is split into two components Mo 3d5/2 and Mo $3 \mathrm{~d} 3 / 2$. The peaks of $\mathrm{Mo}^{6+}$ ion appear at $232.4 \mathrm{eV}$ and $235.5 \mathrm{eV}$ and are present in all samples with molybdenum. $\mathrm{Mo}^{5+}$ peaks are located at 230.2 and $233.3 \mathrm{eV}$ and are present in the samples with 0.04 and $0.08 \mathrm{Mo}$ while in the sample with $0.06 \mathrm{Mo}$ appear peaks at 227.6 and $231.4 \mathrm{eV}$ associated to $\mathrm{Mo}^{4+}$ [25]. The corresponding O1s spectra show three peaks: between $526.3-527.8 \mathrm{eV}$ corresponding to lattice oxygen $\left(\mathrm{O}_{\text {latt1 } 1}\right)$ of copper oxides, $529.5-529.9 \mathrm{eV}$ assigned to lattice oxygen $\left(\mathrm{O}_{\text {latt2 }}\right)$ of iron oxides, and at 531.4-532.4 eV, respectively, due to defect in oxide or to surface oxygen ions $\left(\mathrm{O}_{\text {ads }}\right)[26,27]$. As shown in Table 2, from the XPS spectrum of the last samples after catalytic reaction, an increase of $\mathrm{Cu}^{2+}, \mathrm{Fe}^{3+}$, and $\mathrm{Mo}^{6+}$, respectively, has been observed.

Table 2. Surface composition estimated from XPS.

\begin{tabular}{|c|c|c|c|c|c|c|}
\hline \multirow{2}{*}{ Catalyst } & \multirow{2}{*}{$\mathrm{Cu}^{+} / \mathrm{Cu}^{2+}$} & \multirow{2}{*}{$\mathrm{Fe}^{2+} / \mathrm{Fe}^{3+}$} & \multirow{2}{*}{$\mathrm{Mo}^{5+}\left(\mathrm{Mo}^{4+}\right) / \mathrm{Mo}^{6+}$} & \multicolumn{3}{|c|}{ Surface Composition At (\%) } \\
\hline & & & & $\mathrm{Cu}$ & $\mathrm{Fe}$ & Mo \\
\hline $\mathrm{CuFe}_{2} \mathrm{O}_{4}$ & 0.5 & 0.9 & - & 9.1 & 18.2 & 0 \\
\hline $\mathrm{CuFe}_{1.92} \mathrm{Mo}_{0.04} \mathrm{O}_{4}$ & 0.8 & 0.2 & 0.2 & 9.7 & 12.2 & 4.6 \\
\hline $\mathrm{CuFe}_{1.88} \mathrm{Mo}_{0.06} \mathrm{O}_{4}$ & 0 & 0 & $(0.05)$ & 8.7 & 13.2 & 4.3 \\
\hline $\mathrm{CuFe}_{1.84} \mathrm{Mo}_{0.08} \mathrm{O}_{4}$ & 1.6 & 1.3 & 0.8 & 8.4 & 14.5 & 4.8 \\
\hline $\mathrm{CuFe}_{1.84} \mathrm{Mo}_{0.08} \mathrm{O}_{4}$ (used) & 1.3 & 1.2 & 0.7 & 8.5 & 14.5 & 4.9 \\
\hline
\end{tabular}



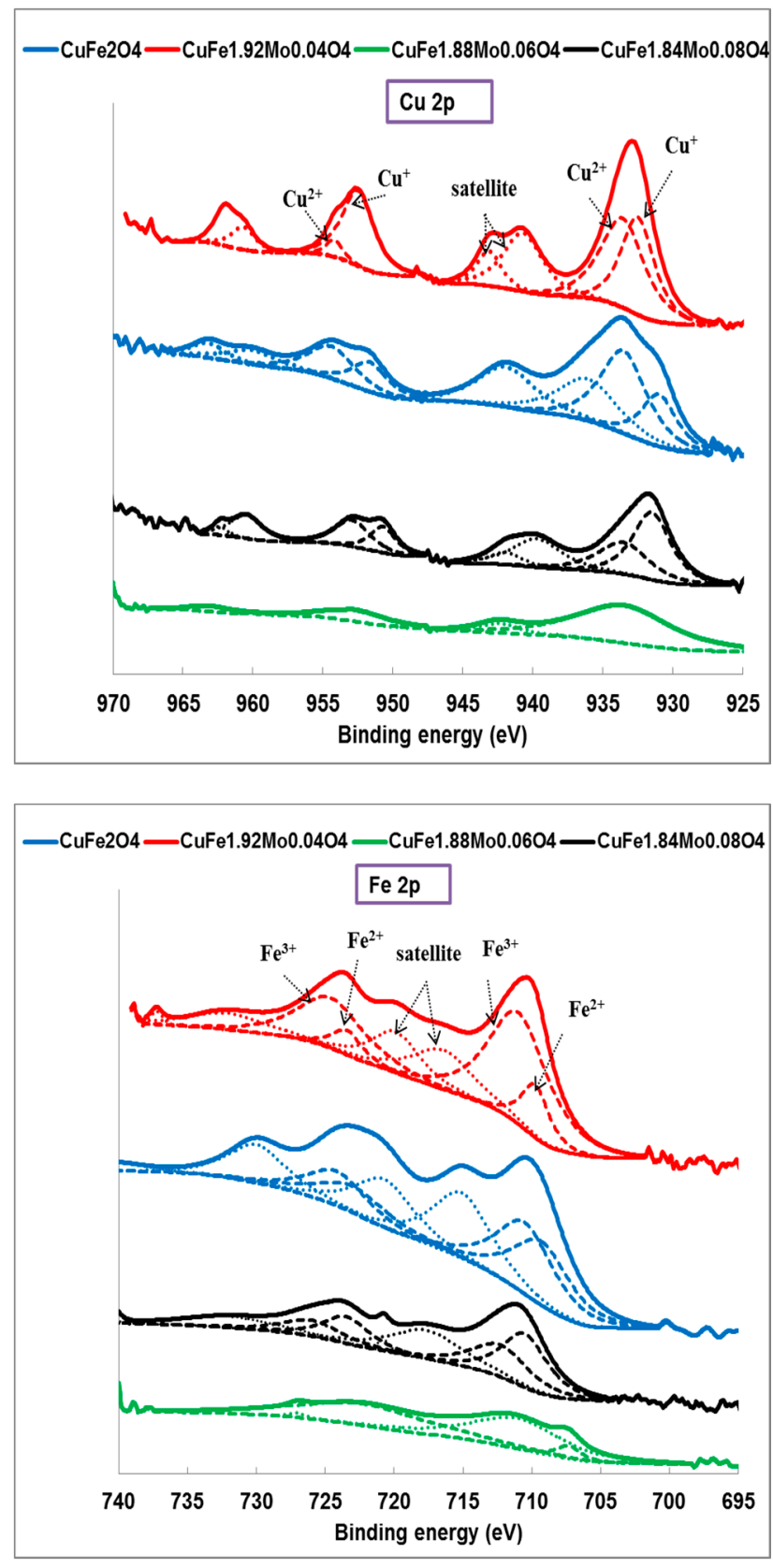

Figure 5. Cont. 

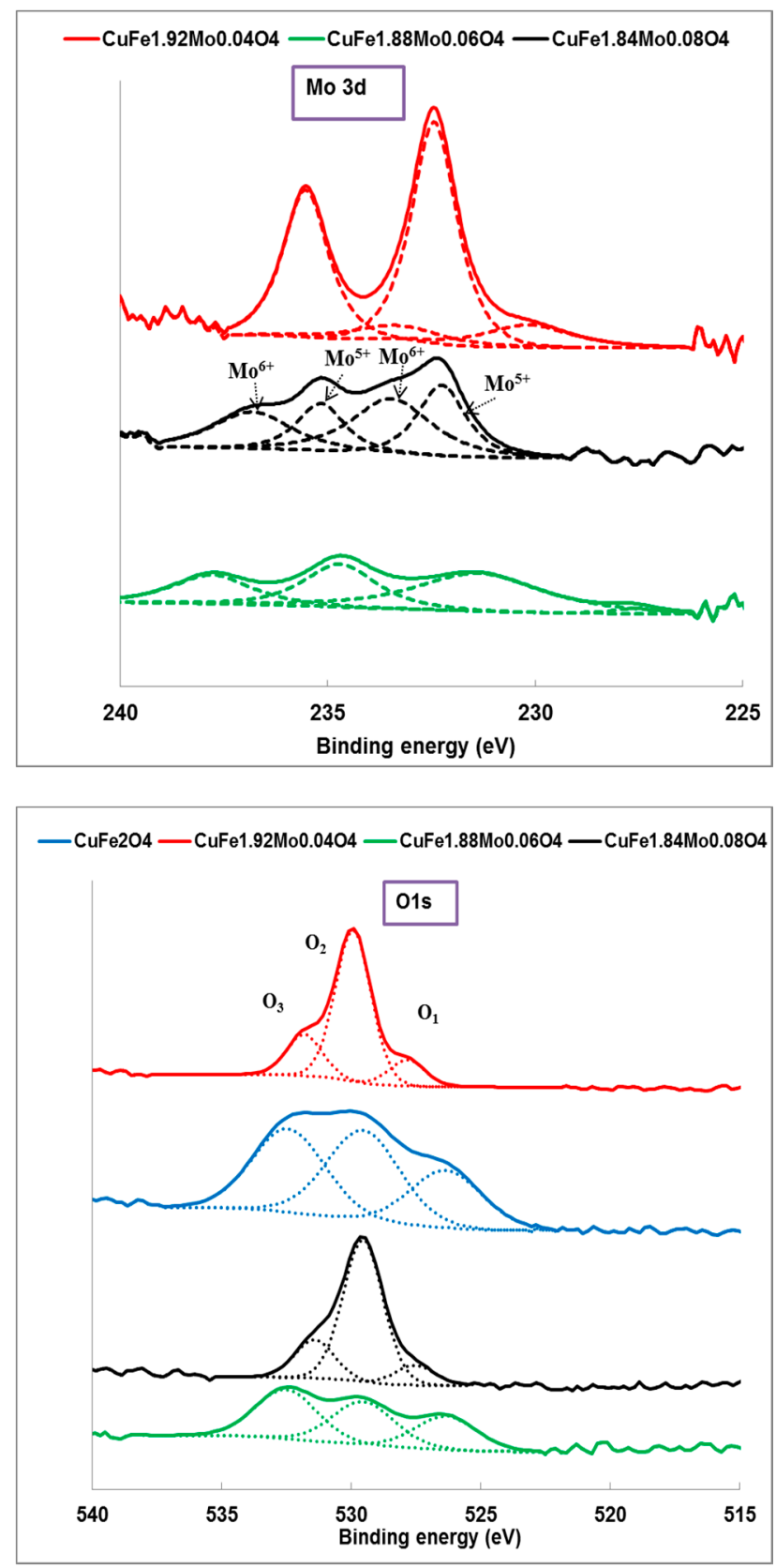

Figure 5. XPS spectra of copper ferrites dopped with molybdenum.

\subsection{Catalysts Activity}

Initial catalytic experiments were carried out in order to investigate the influence of temperature on the catalytic activity and on the products' selectivities. The main products for all catalytic reactions were hydroxyacetone (acetol), ethyl-methyl-ether, methyl acetate, ethyl acetate, and trace of diethyl-ether, dimethyl-ether, acetaldehyde, and formaldehyde. The ethanol conversion and the product distribution are illustrated in Figure 6. The conversion of ethanol has steadily increased with temperature. Concerning the behavior of the four catalysts, it has been observed that the ethanol conversion follows the order: $\mathrm{CuFe}_{1.84} \mathrm{Mo}_{0.08} \mathrm{O}_{4}>\mathrm{CuFe}_{1.92} \mathrm{Mo}_{0.04} \mathrm{O}_{4}>\mathrm{CuFe}_{2} \mathrm{O}_{4}>\mathrm{CuFe}_{1.88} \mathrm{Mo}_{0.06} \mathrm{O}_{4}$. A good correlation between conversion of ethanol and molybdenum composition on the surface has been observed. The methyl-ethyl ether selectivity is higher at low temperature, dehydration reactions occurred faster than dehydrogenation in these conditions. Methyl acetate and hydroxyacetone selectivity increased with temperature, while ethyl acetate has the highest values at $250{ }^{\circ} \mathrm{C}$. On the catalyst without molybdenum 
methyl-ethyl ether is the dominant product at low temperature, whilst at high temperature methyl acetate prevails. Esters are the predominant products on the samples with 0.04 and $0.06 \mathrm{Mo}$, and the sample with 0.08 Mo showed the active sites for hydroxyacetone and ether formation.

The catalytic performances have been evaluated from the apparent activation energies, determined by the slopes of Arrhenius linear plots. The values of apparent activation energies are in the following order: $34,32,38$, and $31 \mathrm{~kJ} / \mathrm{mol}$, respectively.
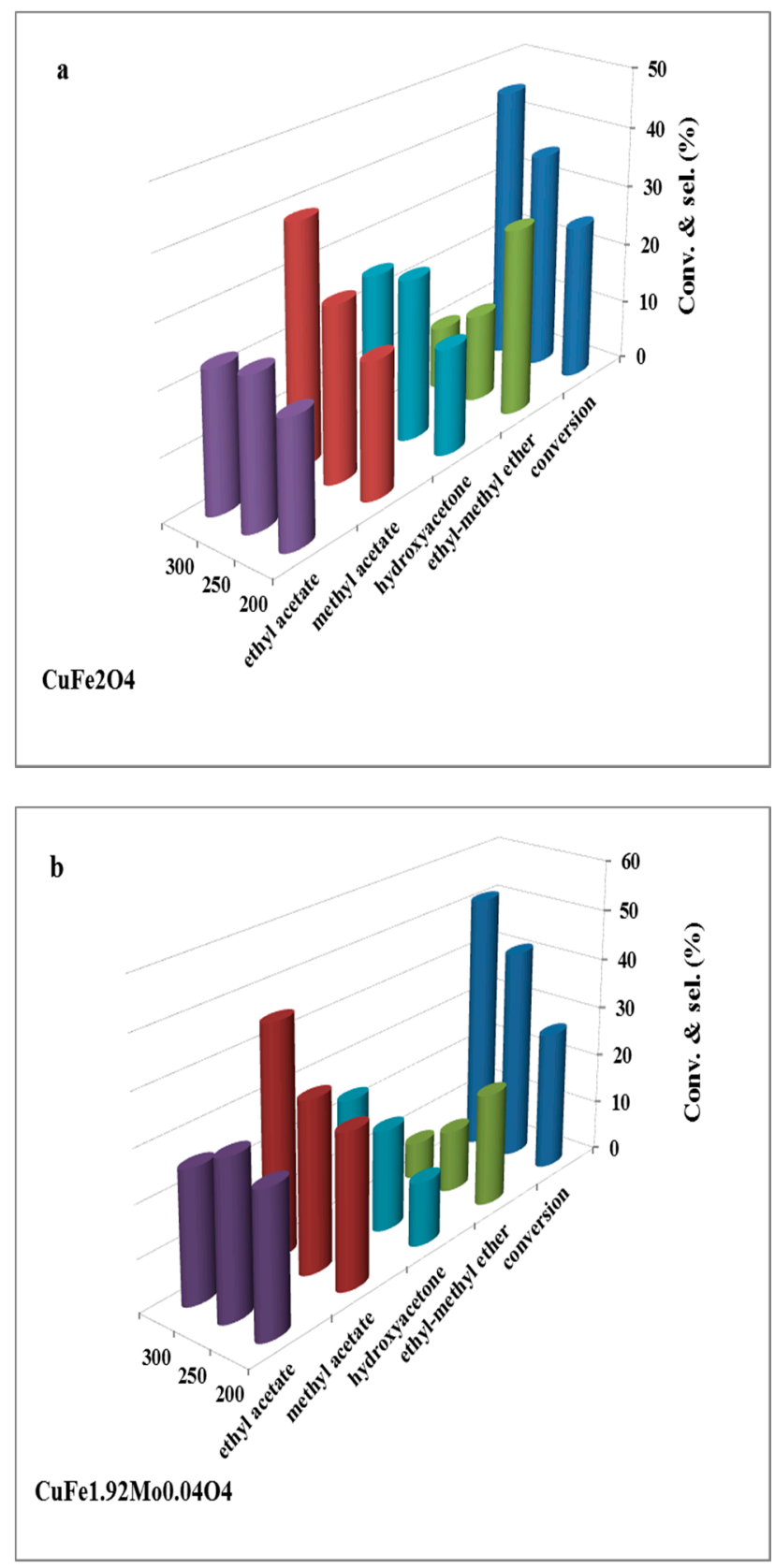

Figure 6. Cont. 

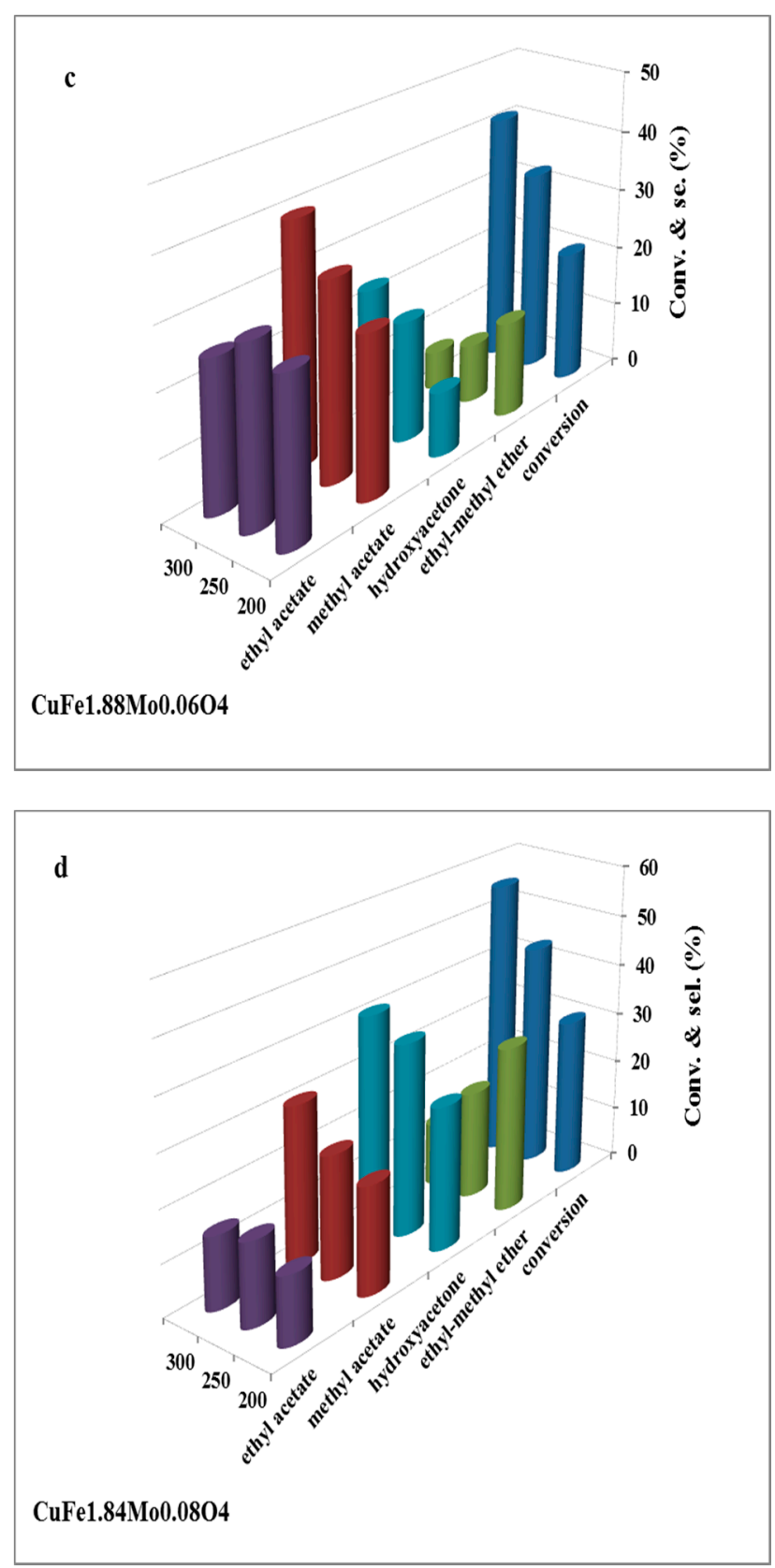

Figure 6. Cont. 


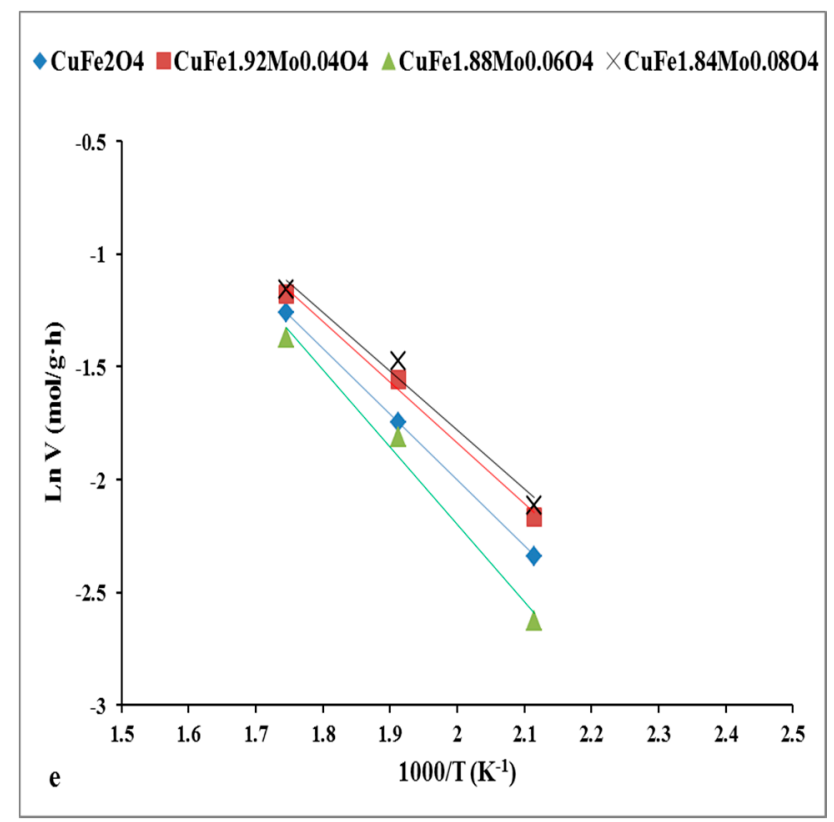

Figure 6. Catalytic performance of copper molybdenum ferrites in the oxidative coupling between methanol and ethanol as function of temperature (reaction conditions: molar ratio methanol:ethanol = 1; liquid fed $0.1 \mathrm{~cm}^{3} / \mathrm{min}$; air flow $3000 \mathrm{~cm}^{3} / \mathrm{min}$; catalyst amount $0.1 \mathrm{~g}$ ), (a) $\mathrm{CuFe}_{2} \mathrm{O}_{4}$, (b) $\mathrm{CuFe}_{1.92} \mathrm{Mo}_{0.04} \mathrm{O}_{4}$, (c) $\mathrm{CuFe}_{1.88} \mathrm{Mo}_{0.06} \mathrm{O}_{4}$, (d) $\mathrm{CuFe}_{1.84} \mathrm{Mo}_{0.08} \mathrm{O}_{4}$, (e) Arrhenius plots for ethanol.

The influence of methanol to ethanol molar ratio on the catalytic activity and on the products selectivities is shown in Figure 7. The presence of methanol in excess leads to an increase in both the catalytic activity and the selectivity to methyl acetate and hydroxyacetone, while the ether and ethyl acetate selectivities are decreasing. 

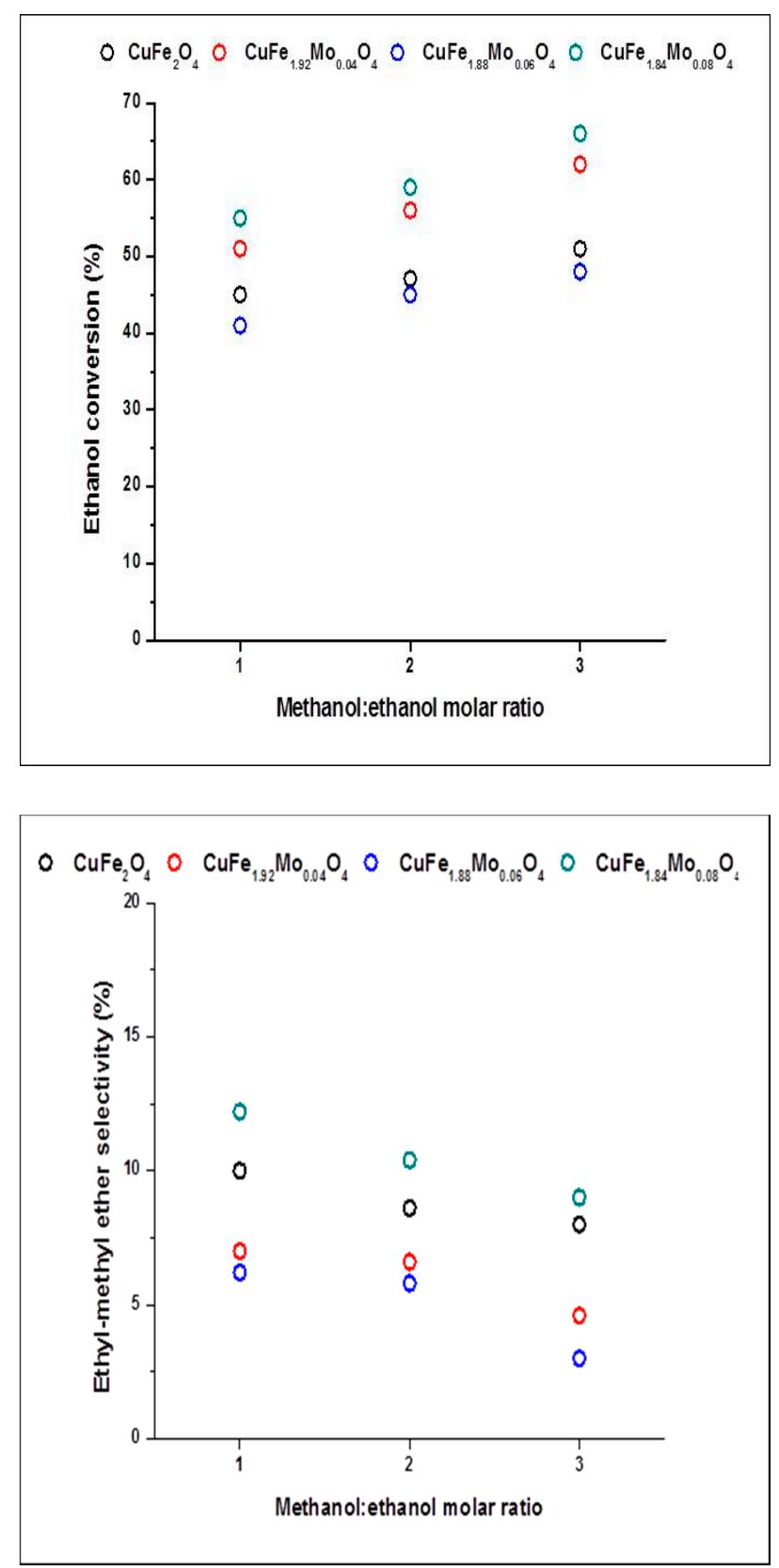

Figure 7. Cont. 

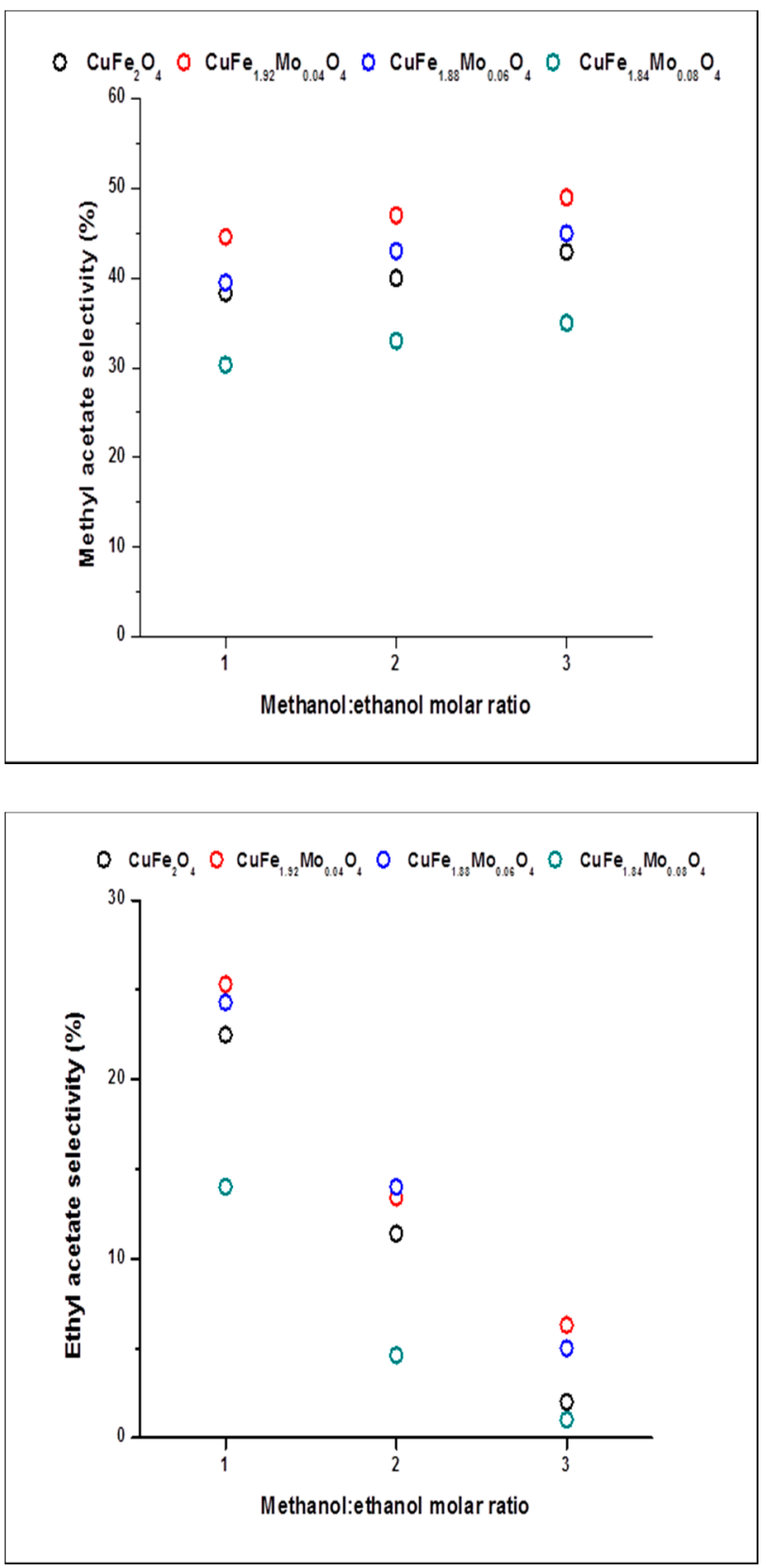

Figure 7. Cont. 


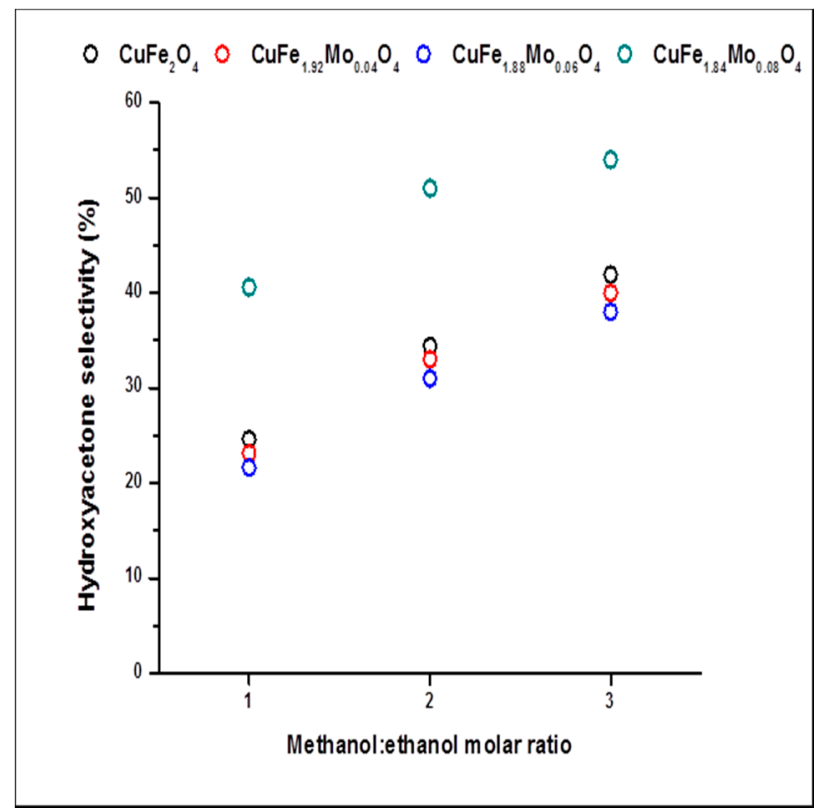

Figure 7. Catalytic performance of copper molybdenum ferrites in the oxidative coupling between methanol and ethanol as function of the methanol to ethanol molar ratio (reaction conditions: temperature $300{ }^{\circ} \mathrm{C}$; liquid fed $0.1 \mathrm{~cm}^{3} / \mathrm{min}$; air flow $3000 \mathrm{~cm}^{3} / \mathrm{min}$; catalyst amount $0.1 \mathrm{~g}$ ).(a) ethanol conversion, selectivity of (b) ethyl-methyl ether, (c) methyl-acetate, (d) ethyl-acetate, (e) hydroxyacetone.

\subsection{Discussion}

Our studies showed that the oxidative coupling and cross-acyloin condensation of methanol and ethanol in the gas phase to produce methyl or ethyl esters and hydroxyacetone are promoted effectively by the copper ferrites dopped with molybdenum.

We noticed that there is a good correlation between catalytic activity and $\mathrm{Cu}^{+} / \mathrm{Cu}^{2+} \mathrm{Mo}^{5+} / \mathrm{Mo}^{6+}$ ratio on the surface, respectively, the catalytic activity being directly proportional to these ratios.

Similar results were obtained by Fan [28] in benzyl alcohol oxidation in the gas phase over mesoporous $\mathrm{K}-\mathrm{Cu}-\mathrm{TiO}_{2}$ catalysts with stable copper (I) oxidation state, noting that $\mathrm{O}_{2}$ acts as an efficient acceptor of hydrogen accelerating the reaction by creation of the free active $\mathrm{Cu}(\mathrm{I})$ sites.

The hydroxyacetone and ether selectivities are directly proportional to the $\mathrm{Fe}^{2+} / \mathrm{Fe}^{3+}$ ratio. However, the reaction perhaps does not occur only on these sites because the sample with $0.06 \mathrm{Mo}$ does not contain this kind of sites and probably on this catalyst the reaction takes place on $\mathrm{Fe}^{0}$ sites.

$\mathrm{Cu}^{2+}$ and $\mathrm{Fe}^{3+}$ act as stronger Lewis acids compared with $\mathrm{Cu}^{+}$and $\mathrm{Fe}^{2+}$, so for this reaction, the presence of weak Lewis acid sites is required. Reductions of $\mathrm{Cu}^{2+}$ to $\mathrm{Cu}^{+}, \mathrm{Fe}^{3+}$ to $\mathrm{Fe}^{2+}$, and $\mathrm{Mo}^{6+}$ to $\mathrm{Mo}^{5+}$ or $\mathrm{Mo}^{4+}$, respectively, take place by gaining an electron from interstitial oxygen. The loss of an electron leads to a high mobilization of the unstable interstitial oxygen that escapes from the lattice and becomes an active oxygen $\left(\mathrm{O}^{-}\right)$.

Methanol and ethanol are converted in ethyl-methyl ether by dehydration or coupling reactions (1):

$$
\mathrm{CH}_{3} \mathrm{OH}+\mathrm{CH}_{3} \mathrm{CH}_{2} \mathrm{OH} \rightarrow \mathrm{CH}_{3} \mathrm{OCH}_{2} \mathrm{CH}_{3}+\mathrm{H}_{2} \mathrm{O}
$$

The ethyl-methyl ether formation takes place on oxides with acid-base properties and is favored by lower reaction temperatures. The ether formation involves the adsorption of two alcohol molecules on the neighbor active sites with different acid-base properties [29]. One alcohol molecule is adsorbed via the oxygen of the $\mathrm{OH}$ group on the weak Lewis acid sites and the second alcohol molecule is adsorbed on the strong basic site through the $\mathrm{H}$ of $\mathrm{OH}$ group with the formation of an alkoxide on the surface. 
Acetaldehyde has been obtained from oxidation (or dehydrogenation) reaction and could react with a new molecule of methanol or ethanol via oxidative esterification giving methyl acetate and ethyl acetate (2), (3):

$$
\begin{gathered}
\mathrm{CH}_{3} \mathrm{CHO}+\mathrm{CH}_{3} \mathrm{OH} \rightarrow \mathrm{CH}_{3} \mathrm{COOCH}_{3}+\mathrm{H}_{2} \\
\mathrm{CH}_{3} \mathrm{CHO}+\mathrm{CH}_{3} \mathrm{CH}_{2} \mathrm{OH} \rightarrow \mathrm{CH}_{3} \mathrm{COOCH}_{2} \mathrm{CH}_{3}+\mathrm{H}_{2}
\end{gathered}
$$

Methyl or ethyl formate has not been observed.

The aldehyde formation by dehydrogenation or by oxidation requires the presence of moderately basic sites $\left(\mathrm{M}^{2+}-\mathrm{O}^{2-}\right)$. In the presence of aldehyde, the esters formation is accelerated with suppression of the secondary aldehydes' oxidation to acids. The aldehyde adsorbed on the surface reacts with an alkoxy group with the formation of a hemiacetal which could eliminate another hydrogen to form an ester. $\mathrm{Xu}$ [30] has demonstrated that the reaction between the methoxy group and different aldehydes to form methyl esters takes place with good results on $\mathrm{O} / \mathrm{Au}$ of nanoporous Au catalysts. Copper based catalysts are known to be active for both hydrogenation and dehydrogenation reactions, enhancing the C-C coupling reaction to esters [22].

The condensation of formaldehyde with acetaldehyde gives as a reaction product, by cross-acyloin condensation, hydroxyacetone (acetol) [3] (4):

$$
\mathrm{CH}_{2} \mathrm{O}+\mathrm{CH}_{3} \mathrm{CHO} \rightarrow \mathrm{CH}_{3} \mathrm{COCH}_{2} \mathrm{OH}
$$

In Scheme 1 we propose a mechanism for acyloin condensation of formaldehyde with acetaldehyde to hydroxyacetone.
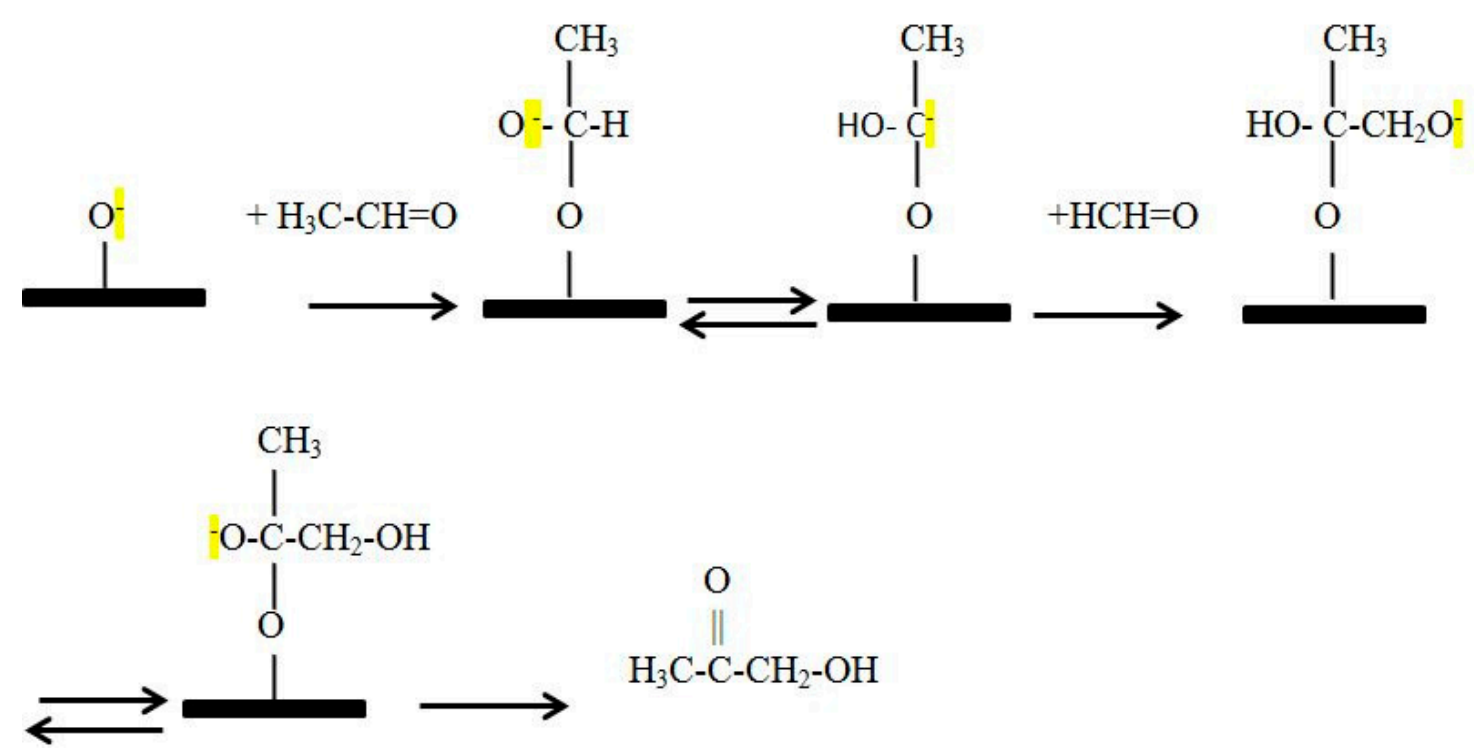

Scheme 1. The reaction mechanism of acyloin condensation of acetaldehyde with formaldehyde.

Acetaldehyde is adsorbed on the surface through oxygen leading to the formation of an oxoanion which can accept a proton from carbon, making it a carbanion. The formed carbanion reacts with formaldehyde with the new $\mathrm{C}-\mathrm{C}$ bond formation and finally to hydroxyacetone.

\section{Experimental Part}

\subsection{Materials and Catalysts' Synthesis}

For the catalysts' synthesis and for catalytic reaction, the following chemicals were used: copper nitrate $\mathrm{Cu}\left(\mathrm{NO}_{3}\right)_{2} \cdot 3 \mathrm{H} 2 \mathrm{O}$ (CAS No.10031-43-3, Carl Roth), ammonium molybdate, $\left(\mathrm{NH}_{4}\right)_{6} \mathrm{Mo}_{7} \mathrm{O}_{24} \cdot 4 \mathrm{H}_{2} \mathrm{O}$ (CAS No: 12054-85-2, FlukaChemika), iron citrate tribasic monohydrate, $\mathrm{C}_{6} \mathrm{H}_{5} \mathrm{FeO}_{7} \cdot \mathrm{H}_{2} \mathrm{O}(\mathrm{CAS}$ No. 
3522-50-7, Sigma-Aldrich), urea (CAS No. 57-13-6, Chimopar), methanol p.a. 99.3\% (CAS No.67-56-1, Consors), and ethanol p.a. 99.5\% (CAS No. 64-17-5, SC Chimreactiv).

Copper ferrites dopped with molybdenum, with the formula $\mathrm{CuFe}_{2-2 x} \mathrm{Mo}_{x} \mathrm{O}_{4}(\mathrm{x}=0,0.04,0.06$ and 0.08$)$, were prepared by substitution of $\mathrm{Fe}^{3+}$ ions with $\mathrm{Mo}^{6+}$. To this end, a mixed aqueous solution of copper nitrate, iron citrate, and ammonium molybdate was used as reagent over which an aqueous solution of urea was added as an organic fuel. The resulting solution by mixing all components was heated at $80-85^{\circ} \mathrm{C}$ until the water was evaporated. The viscous gel obtained was dried at $100^{\circ} \mathrm{C}$ for $24 \mathrm{~h}$ and then was calcined at $200^{\circ} \mathrm{C}, 400^{\circ} \mathrm{C}$, and $600^{\circ} \mathrm{C}$ for $2 \mathrm{~h}$ at each temperature.

\subsection{Catalysts' Characterization}

The Brunauer-Emmet-Teller (BET) surface area and pore size distribution were measured by a Micromeritics ASAP 2020 Surface area and Porosity Analyzer, at $77 \mathrm{~K}$. Before the sorption measurements samples were degassed under vacuum at $200^{\circ} \mathrm{C}$ for $8 \mathrm{~h}$.

The X-ray diffraction patterns were obtained with a PANalyticalX'Pert Pro MRD diffractometer with a $\mathrm{Cu} \mathrm{K} \mathrm{K}_{\alpha}$ radiation. Samples were scanned in the range $5-80^{\circ}$ with a step size of $0.0251^{\circ}$.

The particle size and the morphology of samples were characterized by SEM with an XL-30 Environmental SEM using $20 \mathrm{KeV}$ on samples ground and prepared to a standard.

Infrared spectra were obtained with a Bruker IFS 66 V/S vacuum spectrometer with a diamond attenuated total reflectance (ATR) and with a MIR DLaTGS detector.

The UV-vis-NIR spectra were determined with a UV3600 UV-vis spectrophotometer with a Shimadzu ISR-3100 integrating sphere attachment; the angle of incident light was of $0-8^{\circ}$; the wavelength range was $200-700 \mathrm{~nm}$; two light sources were employed: $\mathrm{A}_{2}$ (deuterium) lamp for the ultraviolet range and a WI (halogen) lamp for the visible and near-infrared range. The samples, before the analysis, were diluted with extra pure barium sulfate (purchased from NacalaiTesque).

X-ray photoelectron spectroscopic (XPS) measurements were carried out using a VG-220IXL spectrometer with a monochromated $\mathrm{Al} \mathrm{K} \alpha$ radiation $(1486.6 \mathrm{eV}$, line width $0.8 \mathrm{eV})$. The pressure in the analyzing chamber was kept at the level of 10-9 torr while recording the spectra. The spectrometer has the energy resolution of $0.4 \mathrm{eV}$. All the binding energies were corrected with reference to $\mathrm{C}(1 \mathrm{~s})$ at $284.8 \mathrm{eV}$. Deconvolution of the spectrum was done using the CASAXPS software with the accuracy of $0.2 \mathrm{eV}$. Shirley background was used for the deconvolution.

\subsection{Catalytic Experiments}

The activity measurements for oxidative methanol-ethanol coupling were carried out in a flow reactor equipped with electronic control of reaction temperature at atmospheric pressure. Reaction temperature was varied in the range $200-300^{\circ} \mathrm{C}$; the catalyst weight was of $0.1 \mathrm{~g}$. Liquid mixture of two alcohols (methanol and ethanol) with different molar ratios (methanol: ethanol ratio was varied in the range 1-3) was fed to the reactor with a pump. The air flow was $3000 \mathrm{~cm}^{3} / \mathrm{h}$ and the liquid mixture was fed with $0.1 \mathrm{~cm}^{3} / \mathrm{min}$. The reaction products were collected periodically and analyzed by gas chromatography with a GC K072320 Thermo-Quest chromatograph equipped with a FID detector. The main products were hydroxyacetone, methyl acetate, ethyl acetate, and ethyl-methyl ether. Acetaldehyde and formaldehyde were also detected in much lower concentrations.

\section{Conclusions}

Copper ferrites dopped with molybdenum are found to be active catalysts for the gas phase oxidative coupling between methanol and ethanol. The main phases that have been highlighted by XRD are copper ferrite with spinel structure, $\mathrm{CuO}$ (tenorite) very well crystallized, and magnetite. Molybdenum is present as isolated tetrahedral species $\mathrm{MoO}_{4}{ }^{2-}$ at a lower Mo content and polymeric octahedral species correlated with an increase in molybdenum content.

The catalytic properties are influenced by the acid-base properties of ferrites, by the composition of defects in oxide, and by the surface oxygen ions. The catalyst with higher $\mathrm{Cu}^{+} / \mathrm{Cu}^{2+}$ and $\mathrm{Mo}^{5+} / \mathrm{Mo}^{6+}$ 
ratios is more active, while the catalyst with higher $\mathrm{Fe}^{2+} / \mathrm{Fe}^{3+}$ ratio is more selective to hydroxyacetone. The presence of $\mathrm{Cu}^{+}, \mathrm{Fe}^{2+}$, and $\mathrm{Mo}^{5+}$ or $\mathrm{Mo}^{4+}$ that act as weak Lewis acid sites is required to lead to a high mobilization of the interstitial oxygen that becomes an active oxygen. This study helped us to understand the oxidative coupling reaction over copper molybdenum ferrites.

Author Contributions: G.M. performed synthesis of materials, catalytic reactions, interpretation of results and writing; S.C. performed material characterization; D.-K.S. contributed to data analysis and writing.

Funding: This research received no external funding

Conflicts of Interest: The authors declare no competing financial interest.

\section{References}

1. León, M.; Díaz, E.; Ordónez, S. Ethanol catalytic condensation over Mg-Al mixed oxides derived from hydrotalcites. Catal. Today 2011, 164, 436-442. [CrossRef]

2. Stošić, D.F.; Hosoglu, S.; Bennici, A.; Travert, M.; Capron, F.; Dumeignil, J.-L.; Couturier, J.-L.; Dubois, A.; Auroux, A. Methanol and ethanol reactivity in the presence of hydrotalcites with $\mathrm{Mg} / \mathrm{Al}$ ratios varying from 2 to 7. Catal. Commun. 2017, 89, 14-18. [CrossRef]

3. Matsumoto, T.; Ohishi, M.; Inoue, S. Selective cross-acyloin condensation catalyzed by thiazolium salt. Formation of 1-hydroxy 2-ones from formaldehyde and other aldehydes. J. Org. Chem. 1985, 50, $603-606$. [CrossRef]

4. Mohamad, M.H.; Awang, R.; Yunus, W.W. A Review of Acetol: Application and Production. Am. J. Appl. Sci. 2011, 8, 1135-1139. [CrossRef]

5. Sato, S.; Akiyama, M.; Takahashi, R.; Hara, T.; Inui, K.; Yokota, M. Vapor-phase reaction of polyols over copper catalysts. Appl. Catal. A Gen. 2008, 347, 186-191. [CrossRef]

6. Kinage, A.K.; Upare, P.P.; Kasinathan, P.; Hwang, Y.K.; Chang, J.S. Selective conversion of glycerol to acetol over sodium-doped metal oxide catalysts. Catal. Commun. 2010, 11, 620-623. [CrossRef]

7. Manova, E.; Tsoncheva, T.; Paneva, D.; Mitov, I.; Tenchev, K.; Petrov, L. Mechanochemically synthesized nano-dimensional iron-cobalt spinel oxides as catalysts for methanol decomposition. Appl. Catal. A Gen. 2004, 277, 119-127. [CrossRef]

8. Vozniuk, O.; Bazzo, C.; Albonetti, S.; Tanchoux, N.; Bosselet, F.; Millet, J.M.M.; Di Renzo, F.; Cavani, F. Structural Changes of Binary/Ternary Spinel Oxides During Ethanol Anaerobic Decomposition. ChemCatChem 2017, 9, 2219-2230. [CrossRef]

9. Pardeshi, S.K.; Pawar, R.Y. Optimization of reaction conditions in selective oxidation of styrene over fine crystallite spinel-type $\mathrm{CaFe}_{2} \mathrm{O}_{4}$ complex oxide catalyst. Mater. Res. Bull. 2010, 45, 609-615. [CrossRef]

10. Florea, M.; Alifanti, M.; Parvulescu, V.I.; Mihaila-Tarabasanu, D.; Diamandescu, L.; Feder, M.; Negrila, C.; Frunza, L. Total oxidation of toluene on ferrite-type catalysts. Catal. Today 2009, 141, 361-366. [CrossRef]

11. Velinov, N.; Petrova, T.; Genova, I.; Ivanov, I.; Tsoncheva, T.; Idakiev, V.; Kunev, B.; Mitov, I. Synthesis and Mössbauer spectroscopic investigation of copper-manganese ferrite catalysts for water-gas shift reaction and methanol decomposition. Mater. Res. Bull. 2017, 95, 556-562. [CrossRef]

12. Han, H.Y.; Wang, S.F.; Tsai, A.P.; Kameoka, S. Catalysts prepared from copperenickel ferrites for the steam reforming of methanol. J. Power Sources 2015, 281, 138-145. [CrossRef]

13. Kubacka, A.; Fernández-García, M.; Martínez-Arias, A. Catalytic hydrogen production through WGS or steam reforming of alcohols over $\mathrm{Cu}, \mathrm{Ni}$ and Co catalysts. Appl. Catal. A Gen. 2016, 518, 2-17. [CrossRef]

14. Hu, W.; Li, D.; Yang, Y.; Li, T.; Chen, H.; Liu, P. Copper ferrite supported gold nanoparticles as efficient and recyclable catalyst for liquid-phase ethanol oxidation. J. Catal. 2018, 357, 108-117. [CrossRef]

15. Singh, R.; Kumar, M.; Khajuria, H.; Sharma, S.; Nawaz Sheikh, H. Studies on hydrothermal synthesis of photolumniscent rare earth $\left(\mathrm{Eu}^{3+} \& \mathrm{~Tb}^{3+}\right)$ doped $\mathrm{NG@FeMoO}$ for enhanced visible light photodegradation of methylene blue dye. Solid State Sci. 2018, 76, 38-47. [CrossRef]

16. Fell, C.R.; Qian, D.; Carroll, K.J.; Chi, M.; Jones, J.L.; Meng, Y.S. Correlation Between Oxygen Vacancy, Microstrain, and Cation Distribution in Lithium-Excess Layered Oxides During the First Electrochemical Cycle. Chem. Mater. 2013, 25, 1621-1629. [CrossRef]

17. Lin, X.; Zhang, Y.; Yin, L.; Chen, C.; Zhang, Y.; Li, D. Y type zeolites/PI membranes for sulfur-free hydrogen source and for fuel cell applications. Int. J. Hydrog. Energy 2014, 39, 642-643. [CrossRef] 
18. Dodi, G.; Hritcu, D.; Draganescu, D.; Radu, D.A.; Popa, M.I. Hexagonal-shaped aminosilane magnetite nanoparticles: Preparation, characterization and hybrid film deposition. Colloids Surf. 2018, 542, 21-30. [CrossRef]

19. Li, Z.; Cheng, B.; Su, K.; Gu, Y.; Xi, P.; Guo, M. The synthesis of diphenyl carbonate from dimethyl carbonate and phenol over mesoporous $\mathrm{MoO}_{3} /$ SiMCM-41. J. Mol. Catal. A Chem. 2008, 289, 100-105. [CrossRef]

20. Rahimi-Nasrabadi, M.; Mahdi Pourmortazavi, S.; Khalilian-Shalamzar, M. Facile chemical synthesis and structure characterization of copper molybdate nanoparticles. J. Mol. Struct. 2015, 1083, 229-235. [CrossRef]

21. Thielemann, J.P.; Ressler, T.; Walter, A.; Tzolova-Müller, G.; Hess, C. Structure of molybdenum oxide supported on silica SBA-15 studied by Raman, UV-Vis and X-ray absorption spectroscopy. Appl. Catal. A Gen. 2011, 399, 28-34. [CrossRef]

22. Bravo-Suarez, J.J.; Subramaniam, B.; Chaudhari, R.V. Vapor-phase methanol and ethanol coupling reactions on CuMgAl mixed metal oxides. Appl. Catal. A Gen. 2013, 455, 234-246. [CrossRef]

23. Tahir, D.; Tougaard, S. Electronic and optical properties of $\mathrm{Cu}, \mathrm{CuO}$ and $\mathrm{Cu} 2 \mathrm{O}$ studied by electron spectroscopy. J. Phys. Condens. Matter 2012, 24, 175002-175010. [CrossRef] [PubMed]

24. Grissa, R.; Martinez, H.; Pelé, V.; Cotte, S.; Pecquenard, B.; Le Cras, F. An X-ray photoelectron spectroscopy study of the electrochemical behaviour of iron molybdate thin films in lithium and sodium cells. J. Power Sources 2017, 342, 796-807. [CrossRef]

25. Lee, Y.J.; Barrera, D.; Luo, K.; Hsu, J.W.P. Hindawi Publishing Corporation, In Situ Chemical Oxidation of Ultrasmall MoOx Nanoparticles in Suspensions. J. Nanotechnol. 2012, 195761. [CrossRef]

26. Wang, X.; Kang, Q.; Li, D. Catalytic combustion of chlorobenzene over $\mathrm{MnOx}-\mathrm{CeO}_{2}$ mixed oxide catalysts. Appl. Catal. B Environ. 2009, 86, 166-175. [CrossRef]

27. Li, H.; Lu, G.; Dai, Q.; Wang, Y.; Guo, Y.; Guo, Y. Efficient low-temperature catalytic combustion of trichloroethylene over flower-like mesoporous $\mathrm{Mn}$-doped $\mathrm{CeO}_{2}$ microspheres. Appl. Catal. B Environ. 2011, 102, 475-483. [CrossRef]

28. Fan, J.; Dai, Y.; Li, Y.; Zheng, N.; Guo, J.; Yan, X.; Stucky, D.G. Low-Temperature, Highly Selective, Gas-Phase Oxidation of Benzyl Alcohol over Mesoporous K-Cu-TiO2 with Stable Copper(I) Oxidation State. J. Am. Chem. Soc. 2009, 131, 15568-15569. [CrossRef]

29. Di Cosimo, J.I.; Apesteguía, C.R.; Ginés, M.J.L.; Iglesia, E. Structural Requirements and Reaction Pathways in Condensation Reactions of Alcohols on MgyAlOx Catalysts. J. Catal. 2000, 190, 261-275. [CrossRef]

30. Xu, B.; Madix, R.J.; Friend, C.M. Achieving Optimum Selectivity in Oxygen Assisted Alcohol Cross-Coupling on Gold. J. Am. Chem. Soc. 2010, 132, 16571-16580. [CrossRef] 